\title{
Wielcy ludzie i my (Z cyklu Niedzielne rozmowy)
}

Trie udzie wielcy czują się zwykle samotni. I wcale nie dlatego, że są dumni, nie dlatego, że „pogardzają” miernotą. Samotni są dlatego, że nie ma wokół nich ludzi im równych. Muszą milczeć albo spotykają się z niezrozumieniem. Nie rozumie ich ten, kto nie chce zrozumieć albo nie może. A ponieważ każdy z nas skłonny jest myśleć, że jest w stanie wszystkich zrozumieć - przecież nie jest głupszy od innych - ci, którzy nie rozumieją wielkiego człowieka, zwykle gniewają się nań lub się obrażają. To nie wielki człowiek, lecz oni, ludzie, być może nawet dosyć ważni, ale nie dorównujący wielkiemu człowiekowi, unoszą się dumą, a niekiedy wpadają rozdrażnienie. "Cóż za marzyciel!”, „co za dziecięcy romantyzm”, „jaka zarozumiałość!” - myślą o wielkim człowieku i odsuwają się od niego.

Do wielkiego człowieka zbliżyć się mogą ci, którzy może i nie zawsze go rozumieją, ale wierzą mu i kochają go. Są to ludzie otwartego ucha, ludzie intuicji. Wielki człowiek uwalnia ich od wątpliwości, wyzwala ich, do tej pory spętaną, wolę, przekształca ich potencjalną energię w działanie i przez to czyni szczęśliwymi.

Im bardziej pozostają wierni swojemu mistrzowi, im bardziej gotowi są wykonywać zamysły mistrza, tym bardziej stają się nierówni wielkiemu człowiekowi. Wybrali go na swego mistrza. Jest dla nich niekwestionowanym autorytetem. Nie peszy ich to, że czasem nie zgadają się z nim. Wewnętrzna skromność podpowiada im, że niezgoda ta wynika z niezrozumienia. Nie rozumieją przecież tylko dlatego, że są pozbawieni tej mądrości, tej zdolności przewidywania, które posiada ich mistrz i wódz, przez nich i z ich woli wybrany.

Człowiek wielki, gdyby dobrze poszukał, mógłby wprawdzie znaleźć równych sobie, swoich ojców duchowych. Ale zwykle równych sobie znaj- 
duje tylko w przeszłości, w historii, w książkach. Ze współczesnymi, nawet wielkimi, dojść do porozumienia nie może. Spotkanie Napoleona z Goethem, a także ich rozmowa, jest jednym z najbardziej nieprzyjemnych, nieartystycznych oraz fałszywych wydarzeń historii powszechnej. Arcykulturalny burżua-kontemplator patrzył na Napoleona prawie niczym doświadczony psychiatra, Napoleonowi zaś (który „jak boże błyskawice”1) jasne, bezchmurne niebo Goethego było głęboko obce. Goethe zwyciężał świat zewnętrzny przyjmując go, jakim jest, licząc się z jego niezmiennymi prawami. Napoleon zaś walczył ze światem zewnętrznym, chciał przezwyciężyć jego bezwład. Goethe był świadom „okropnej mocy codzienności”(Die Macht der Alltäglichkeit), ale wyzwalał się z niej poprzez podporządkowanie się jej. Ze współczuciem patrzył na zbuntowanego Napoleona, który szukał burzy, „jak gdyby w burzach spokój był”2. Napoleon przeciwstawiał się wszechpotężnej codzienności i myślał, że stwarza dla ludzkości nową racjonalną codzienność. Zbyt genialni i oryginalni byli to rozmówcy, aby mogli się porozumieć. Grzecznie więc kłaniając się sobie nawzajem, rozeszli się. Często jednak rozstania wielkich ludzi bywają bardzo nieuprzejme.

W młodości dziwiła mnie jakaś ślepa wrogość panująca między naszymi trzema wielkimi pisarzami: Turgieniewem, Dostojewskim i Tołstojem. Dzisiaj, gdy zbliżam się ku starości, dziwi mnie moja młodzieńcza naiwność. Wzajemne odpychanie się ludzi wielkich jest raczej świadectwem ich wzajemnego szacunku, niż obojętnego niezrozumienia. Przecież nawet w nienawiści więcej jest szacunku dla przeciwnika, niż w pobłażliwej obojętności.

Geniusz jest zbyt oryginalny, aby nie być samotnym...

II.

Z tego powodu trudno pisać o wielkich ludziach, $\mathrm{z}$ tego powodu tak bardzo sprzeczne są wspomnienia ich współczesnych, z tego właśnie powodu do tej pory nie ma wyczerpującej biografii Goethego czy Napoleona. $\mathrm{Z}$ jednej strony odkrywane są coraz nowe materiały - dopiero co została odnaleziona korespondencja Napoleona z Marią Luizą - z drugiej strony, każde pokolenie na nowo, pod nowym kątem patrzy na swoich wiecznych współtowarzyszy, na ludzi wielkich.

Wszystkie te banalne myśli stały się dla mnie nad wyraz aktualne i konkretne w związku z odejściem do wieczności Marszałka Piłsudskiego.

Roman Zrębowicz ${ }^{3}$, człowiek bardzo inteligentny i niewątpliwie utalen-

Z wiersza Michaiła Lermontowa Żagiel. Przekład Tadeusza Stępniewskiego.

2 Z poematu Połtawa Aleksandra Puszkina (Pieśń trzecia). Cytata w przekładzie Mieczysława Jastruna. Ten i następne przypisy, o ile nie są oznaczone „Przyp. aut.”, pochodzą od tłumaczy.

3 Boris Sawinkow (1879-1925), jeden z przywódców partii eserów, terrorysta, pisarz. W 1924 
towany, który jednak z przyczyn mi nieznanych pogrzebał swój talent, opublikował nie tak dawno artykuł pod tytułem Zwiedzanie Sulejówka („Tygodnik Ilustrowany”, nr 23).

Artykuł ten jest niewymyślny, skromny i bardzo interesujący. Zrębowicz opowiada, jak odwiedził Piłsudskiego jesienią w 1923 roku w Sulejówku, gdzie schronił się Marszałek po wyborze pana Wojciechowskiego na prezydenta Rzeczpospolitej. Od tego momentu przeszedł Marszałek do „opozycji”. Podczas pobytu w Sulejówku orzeł przygotowywał się do lotu, do majowych dni 1926 roku. Zrębowicz z artystyczną prostotą opisał ten, niczym nie wyróżniający się wśród innych, skromny domek. Opisał zgrzebny, wręcz ubogi krajobraz Sulejówka, sosny i piaski, a następnie przytoczył w skrócie treść swojej rozmowy z gospodarzem.

We wstępie zaś do swojego artykułu poczynił następującą uwagę:

"Jest obowiązkiem całego obecnego pokolenia, a przede wszystkim tych, którzy mieli szczęście - i zaszczyt osobistego zetknięcia się z nieśmiertelnym twórcą odrodzonej ojczyzny - zbierać te szczegóły choćby najskromniejsze i podawać je do publicznej wiadomości”.

Wydaje mi się, że Zrębowicz ma rację i że jego uwaga może dotyczyć i mnie osobiście.

Też jeździłem do Sulejówka, i też jesienią.

Pojechałem tam zupełnie załamany, powiem bez fałszywego wstydu w całkowitej rozpaczy. Dopiero co dokonała się zdrada Borysa Sawinkowa ${ }^{4}$. Nie chcę go teraz osądzać. Można powiedzieć, że przez swoją śmierć odkupił swoją winę. Ale wtedy, jesienią 1924 roku, uznałem jego postępek za niewybaczalne sprzeniewierzenie się, za zdradę. Wydawało mi się, że ziemia się pode mną rozstępuje. Pojechałem więc do Sulejówka. Nie za bardzo rozumiałem, po co tam jadę, ale całym swym jestestwem czułem, że rozmowa ta będzie rozstrzygająca ${ }^{5}$. Tylko Piłsudski potrafi przynajmniej odrobinę rozjaśnić tę ciemność nieprzejrzaną, w którą wpadłem, a może, jeśli tylko zechce, podtrzyma mnie na duchu...

Po śmierci Marszałka zastanawiałem się nad tym, czy nie spoczywa na mnie obowiązek przynajmniej zapisania, jeśli nie publikacji, wszystkiego, co pozostało w mojej pamięci z rozmów z Marszałkiem i obcowania z nim. Rozmów i spotkań miałem niewiele, może z dziesięć, a może piętnaście, a i to w ciągu pięciu, sześciu lat. Ale taki już był Piłsudski, że rozmowy z

wrócił nielegalnie do Rosji, został aresztowany i osądzony. W więzieniu popełnił samobójstwo. 4 Roman Zrębowicz (1884-1963), krytyk literacki, historyk sztuki, redaktor, po 1945 kustosz w Muzeum Sztuki w Łodzi.

5 Z korespondencji Fiłosofowa wynika, że postanowił niejako „oddać się do dyspozycji” Piłsudskiego. Uważał, że zdrada Sawinkowa rzuca cień na jego działalność i być może powinien opuścić Polskę. Przywiózł Piłsudskiemu wszystkie listy, jakie otrzymywał od Sawinkowa. 
nim zawsze były znaczące. Obcych ludzi przyjmował niechętnie, ale jeśli już przyjmował, to wtedy nie oszczędzał siebie. Nie żałował sił. Właśnie w Sulejówku rozmowa nasza była nadzwyczaj długa i kosztowała Marszałka dużo wysiłku. Dzięki Zrębowiczowi moja wizyta w Sulejówku nadzwyczaj jasno stanęła w mojej pamięci. Prócz tego, jego artykuł przekonał mnie, że powinienem niezwłocznie napisać o swoich spotkaniach z Marszałkiem. To nie tylko obowiązek, jak mówi Zrębowicz, to oczywisty dług. Przecież wróciłem wtedy z Sulejówka zupełnie inny. Stałem znowu na ziemi. Marszałek jak błyskawicą rozjaśnił ciemność nieprzejrzaną, dodał otuchy, podtrzymał. Tak, trzeba pisać. Zdaje mi się, że mam do tego prawo.

Ależ teraz powstaje pytanie - jak pisać?

Mówiłem powyżej, jak bardzo nasze sądy o ludziach wielkich są zawężone, jednostronne, a nawet mylne. Zresztą, w artykule tak łatwo wykazać się brakiem uwagi wobec osoby zmarłego Marszałka, tak łatwo dopuścić się nietaktu, powiedzieć coś, co nie było przeznaczone do publikacji, a nawet po prostu zniekształcić jego myśl.

By dodać sobie otuchy, zacząłem interesować się tym, co opublikowano po śmierci Marszałka. Powinienem powiedzieć bez ogródek, że mnie to nie zbudowało. Wręcz przeciwnie, moje wątpliwości wzrosły, uzyskałem nowe dowody na to, jak ciężko pisać o człowieku niezwykłym, o człowieku takiego formatu jak Józef Piłsudski.

III.

Wśród publikacji, które ukazały się po śmierci Marszałka Piłsudskiego, nadzwyczaj interesującą i ważną wydała mi się książka pana Wasilewskiego $^{6}$ Jozef Piłsudski - jakim go znałem ${ }^{7}$.

Wybitny działacz PPS, współtowarzysz Piłsudskiego, poczynając od dziewięćdziesiątych lat ubiegłego wieku, minister spraw zagranicznych w gabinecie Moraczewskiego (t.j. gabinecie, utworzonym z inicjatywy Piłsudskiego, kiedy wrócił z twierdzy Magdeburskiej), zwolennik polityki federacyjnej Marszałka, p. Wasilewski miał kontakty z Piłsudskim do początku maja 1926 roku. Ostatni raz widział Marszałka na kilka dni przed przewrotem majowym. Po wydarzeniach majowych p. Wasilewski zrezygnował z czynnej działalności politycznej i przeszedł na, jeśli można tak rzec, pozycje „neutralności przyjacielskiej”. Podjął się specyficznej pracy, o charakterze raczej

\footnotetext{
${ }^{6}$ Leon Wasilewski (1870-1936), działacz PPS, PPS-Frakcji Rewolucyjnej i Polskiej Organizacji Wojskowej. 1918-1919 - minister spraw zagranicznych, współtwórca Traktatu Ryskiego, kończącego wojnę polsko-bolszewicką. Od 1924 prezes Instytutu Badania Najnowszej Historii Polski, redaktor naczelny czasopisma „Niepodległość”.

${ }^{7}$ L. Wasilewski, Józef Piłsudski - jakim go znałem. Warszawa 1935. Przyp. aut.
} 
technicznym: redagował niektóre tomy esejów Marszałka, a w końcu, zajął stanowisko redaktora naczelnego czasopisma „Niepodległość”. Czasopismo to przypomina nasze „Былое”8, z początku wydawane przez W. L. Burcewa ${ }^{9}$, a później przez W. J. Jakowlewa-Boguczarskiego ${ }^{10}$ i P. J. Szcziogolewa ${ }^{11}$.

Z tej krótkiej noty informacyjnej widać, na ile książka p.Wasilewskiego powinna być solidna, z jakim zaufaniem należy traktować materiał, przedstawiony przez autora. Materiał ten w wielu miejscach jest najwyższej próby, pierwszorzędny. Autor to przecież nie tylko wybitny działacz polityczny, ale też doświadczony publicysta, spokojny, opanowany, niewątpliwie dążący do obiektywizmu. Krótko mówiąc, wydawałoby się, że nie ma powodu do wątpliwości. Oto wzór, przykład, jak należy pisać osobiste wspomnienia o zmarłym Marszałku.

Jednak właśnie ta „obiektywna” książka, pisana przez osobę tak kompetentną, mającą autorytet, przekonała mnie nadzwyczaj dobitnie, jak ciężko jest pisać o wielkich ludziach i jak fałszywie mogą brzmieć najbardziej autentyczne słowa Marszałka Piłsudskiego, jeśli brać je w stanie surowym, nie uwzględniając przy tym ani czasu, ani okoliczności.

Szczerze mówiąc, akurat wysoka pozycja autora i jego bliskie relacje z Piłsudskim, zwłaszcza w tamtych latach, kiedy Marszałek był z początku „towarzyszem Wiktorem”, nazwiska którego p. Wasilewski nie znał, a później "Ziukiem” (t.j. skrót od Józef ${ }^{12}$ ), to jednak najbardziej znaczące przeszkody, których nie napotykają ludzie, będący daleko od Marszałka, zajmujący wyjątkowo skromną pozycję. Wracając zaś do mej osoby, moje „położenie” w tak pojmowanym sensie jest bardziej korzystne.

Ciekawa książka p. Wasilewskiego budzi jednak poważne zakłopotanie nie tylko dlatego, że autor jest autorytetem, ale również i dlatego, że pominął niezwykle ważną okoliczność. Nie wziął pod uwagę tego, że choć Marszałek odszedł był do wieczności, to duch jego wciąż żyje w Polsce i przez długi czas jeszcze będzie oddziaływał na jej losy i historię.

Natomiast, jak mi się wydaje, właściwie zrozumiał to p. Jan Parandowski w błyskotliwym artykule Глагол Времени ${ }^{13}$. Tak zdaje się należałoby prze-

\footnotetext{
8 „Byłoje” - czasopisma poświęcone historii ruchu rewolucyjnego, ukazywało się od 1900, początkowo w Paryżu, w latach 1906-1907 w Rosji, następnie znów w Paryżu, od 1917 w Piotrogrodzie, aż do zamknięcia w 1926.

9 Władimir Lwowicz Burcew (1862-1942), publicysta, wydawca, historyk ruchu rewolucyjnego w Rosji.

${ }^{10}$ Wasilij Jakowlewicz Jakowlew-Boguczarski (1861-1915) pisarz, publicysta, dziennikarz.

11 Pawieł Jelisiejewicz Szcziogoliew (1877-1931), historyk literatury, puszkinista.

12 „Ziuka” zastąpiono „Komendantem” przed samą wojną, gdy Piłsudski doszedł do wniosku, że do osiągnięcia niepodległości konieczne jest zorganizowanie polskich sił zbrojnych. Najbliżsi Marszałkowi „piłsudczycy” do dziś nazywają swego wodza - „Komendantem”. Przyp. aut.

13 „Wiadomości Literackie” 1935, nr 23. Przyp. aut.
} 
tłumaczyć tytuł artykułu p. Parandowskiego Godzina Historii na język rosyjski. Jak do chwili obecnej w Polsce, o ile ona istnieje i chce istnieć, żyją duchy Jagiełły, Stefana Batorego, tak samo żyje w niej i żyć będzie duch Piłsudskiego, który, nawiasem mówiąc, przez długi czas posiadał tytuł „Naczelnika Państwa”, związany z pamięcią o Kościuszce.

Dodam, że jeśli można coś zarzucić Parandowskiemu, to tylko, że nie wyprowadził postaci historycznej Piłsudskiego poza obszar historii Polski. Oprócz Parandowskiego ten sam „błąd” (jeśli można w tym wypadku mówić o „błędzie”) popełnia wielu Polaków, przez co jakby wykreślają cudzoziemców z kręgu osób, mogących, tak czy inaczej, docenić znaczenie Piłsudskiego jako żywego przykładu „roli osobowości w historii”. Dla mnie, cudzoziemca, zmarły Marszałek jest drogi właśnie w tym względzie. Podobnie zapewne i dla innych cudzoziemców. Dla nas, obcych, nie uczestniczących w historii Polski, Piłsudski powinien zająć miejsce w Żywotach równoległych Plutarcha. Pan Wasilewski natomiast zanadto zawęził postać Piłsudskiego. Przede wszystkim, uparcie obstając przy „moskalofobii” zmarłego Marszałka. Przez to jakby nie pozwalał Rosjanom pisać o nim.

Według słów Mojżesza nie wolno gotować koźlątka w mleku jego matki. A więc, jeśli Rosjanin bierze na siebie śmiałość przyznania wielkości takiej osobowości, jak Piłsudski, to przez to staje się koźlątkiem, które samo siebie skazuje na ugotowanie w mleku własnej matki.

Myślę jednak, że to nie tak. Postać Piłsudskiego jest o wiele większego formatu niż sądzi p. Wasilewski. Jako wybitny i wielki człowiek Marszałek należy nie tylko do Polaków, a tym bardziej nie tylko do jednej polskiej partii.

26 maja 1926 roku powiedział: „Osobiście nigdy nie chciałem być członkiem ani polskiej prawicy, ani polskiej lewicy. Nie chciałem nigdy należeć do żadnego stronnictwa, ani też aprobować panowania stronnictw nad Polską"14.

Piłsudskiego nie wolno rozpatrywać częściowo. Trzeba nań patrzeć ca-łościowo. Właśnie na tym polega zasadnicza trudność, przed którą stają wszyscy piszący o nim, trudność, której nie można przezwyciężyć. Na tym polega problem wszystkich „Plutarchów”, a zwłaszcza wszystkich zwykłych śmiertelników, którzy w jakimś stopniu stykają się z wielkimi ludźmi oraz mają jakieś osobiste, związane z nimi wspomnienia. Przemieniają oni człowieka żywego w „bożka na spiżowym koniu”, albo nieświadomie go pomniejszają, czynią z niego człowieka takiego, jak my wszyscy.

Należy nieco bliżej zapoznać czytelnika z książką p. Wasilewskiego, aby to, co piszę, nie wydało się gołosłowne.

14 „Wywiad ogłoszony w „Kurierze Porannym” 27 maja 1926, w: J. Piłsudski, Pisma zbiorowe, Instytut J. Piłsudskiego, Warszawa 1937, t. IX, s. 24-25. 
IV.

W wydanej w ostatnio książce p. Leon Wasilewski, według mnie, zniekształcił wizerunek Piłsudskiego. Uczynił to nieświadomie, bo nie zamierzał w najmniejszym stopniu zniekształcać faktów, czy być nieobiektywnym.

Postać zmarłego Marszałka uległa nie tyle zniekształceniu, co uproszczeniu.

Jeśli któryś z wybitnych uczestników wojny napisze nawet najbardziej obiektywne i prawdziwe wspomnienia wojenne o tym odcinku wielkiego frontu, na którym dzielnie walczył, to jako autor wspomnień, nieświadomie, wbrew swojej woli nadmiernie uwypukli akurat ten odcinek. Ów odcinek frontu może mieć wielkie znaczenie taktyczne, niemniej jednak zadań strategicznych całego frontu historia jednego odcinka odzwierciedlić nie może.

W swojej krótkiej historii wojny francusko-pruskiej feldmarszałek Moltke wysuwa aksjomat, który głosi, że nie ma takiego sukcesu taktycznego, którego nie można wykorzystać dla sukcesu strategicznego. Rzecz jasna, polski Marszałek w swoim zupełnie niebywałym życiu oraz swojej działalności umiejętnie wykorzystywał zwycięstwa taktyczne na poszczególnych odcinkach frontu w celu osiągnięcia swoich planów strategicznych. Nie wszyscy jednak mogli być wtajemniczeni w owe plany, nawet najbliżsi.

Oto po raz kolejny doświadczamy „niedostępności” ludzi wielkich.

W tym wypadku sprawa jeszcze bardziej się komplikuje przez to, że Piłsudski jako działacz polityczny wyrósł w konspiracji, był nią wręcz przesiąknięty. Uwzględniając to, nie wolno jednak mieszać niedostępności sekretu konspiracyjnego z niedostępną „Tajemnicą” ludzi wielkich. Można wiedzieć o sekretach konspiracyjnych wielkiego człowieka, ale nie poznać jego „Tajemnicy” i odwrotnie, można odczuć magię jego "Tajemnicy” i nie poznać jego „sekretów”, a nawet nie zwrócić na nie uwagi.

W Dziewiątej symfonii Beethovena albo w Ekstazie Skriabina nie ma żadnych „sekretów”, tak samo jak w wierszach Norwida czy Rimbauda. Jednak twórcza „Tajemnica” tych kompozytorów i poetów była sferą niedostępną, nie dającą się poznać prawie nikomu ze współczesnych. Jedynie następne pokolenia posiadły ją, kiedy stało się możliwe spojrzenie z pewnego dystansu. Z perspektywy czasu bowiem możemy się zbliżyć ku ludziom wielkim. Na podstawie tego można wnioskować, że tajemnica Piłsudskiego także nie może być odkryta do końca przez współczesnych. Można jedynie odczuwać ją jako magię, oraz jej ulegać. Racjonaliści wszystkich odcieni przyzwyczaili się oceniać ludzi oraz ich działalność przy pomocy trzeźwego umysłu. Sekrety konspiracyjne akceptują, są w stanie godzić się z ich istnieniem. Ale „Tajemnicy” przyjąć już nie mogą. Traktują to jako zdradę swoich przekonań. 
Dlatego ćwiartują życie wielkich ludzi na odrębne części. Część akceptując, część odrzucając. Przez to ograniczają człowieka wielkiego, upraszczają, a może nawet zabijają w nim to, co jest najwyrazistszym przejawem pełni życia i oryginalności .

Wyjaśnijmy to na przykładzie chociażby Lwa Tołstoja, czy Mickiewicza. Jedni poszli za Tołstojem, kiedy odrzucił przesądy swojego „średnio-wyższego” środowiska, wyrzekł się „sztuki czystej”, słowem został „tołstojowcem”. Inni, odwrotnie, nie zaakceptowali „tołstojostwa”, i stwierdzili, że biografia Lwa Tołstoja kończy się na Annie Kareninie. Jeśli przed Spowie$d z i q^{15}$ rosyjskie kręgi postępowe unikały Tołstoja, to gdy stał się „tołstojowcem” właśnie te same kręgi rehabilitowały wielkiego pisarza, idącego, według nich, do tej pory na rękę „reakcji”. To samo stało się z Mickiewiczem. W tym wypadku przyczyną obrazy była jego fascynacja Towiańskim.

Wielkiego człowieka nieuchronnie czeka nieszczęście, jeśli, ulegając własnemu wewnętrznemu głosowi, zmierza w kierunku niezrozumiałym dla współczesnych i swoich zwolenników. Jego genialne przeczucia i przewidywania zaczynają być oceniane „trzeźwym umysłem”, oceniane, a czasem i sądzone.

Nieliczni tylko pozwalają ludziom wielkim mieć swoje zdanie, myśleć, działać i tworzyć po swojemu.

Kiedy 26 maja 1926 na bankiecie w hotelu Bristol Marszałek oświadczył, że nigdy nie chciał należeć do żadnego obozu, wszystko jedno czy prawego, czy lewego oraz, że nigdy nie chciał należeć do żadnej partii, to jasne było, że wielu jego współtowarzyszom partyjnym owe słowa nie były miłe. Później, po pewnym wydarzeniu związanym z wyborami, zakłopotanie i strapienie jeszcze bardziej wzrosły.

Dziś tych tragicznych rozbieżności nie da się wyjaśnić. Konieczna jest perspektywa czasu. Można powiedzieć tylko jedno. Pojęcie „wodza” dla Piłsudskiego wcale nie łączyło się z ustalonym pojęciem „lidera partii politycznej” albo „premiera” republiki parlamentarnej.

Ledru-Rollin ${ }^{16}$, członek francuskiego rządu rewolucyjnego w 1848 roku, powiedział: „jestem ich wodzem, więc powinienem iść za nimi”.

Piłsudski jest żywym zaprzeczeniem tej mądrej maksymy. „Jeśli jestem waszym wodzem - mówi - powinniście iść za mną."

Właśnie na tym polegało jego przeznaczenie. Przez całe życie szedł pod prąd, nawet wtedy, kiedy zdobył władzę. Był żywym uosobieniem tej filozofii, która uznaje rolę osobowości w Historii.

\footnotetext{
15 Spowiedź - broszura Lwa Tołstoja, w której autor potępia cerkiew prawosławną, oraz głosi konieczność odnowy religijnej. Spowiedź legła u podstaw „tołstojowstwa” jako postawy i ruchu społecznego. 16 Alexandre Ledru-Rollin (1807-1874), francuski publicysta, polityk, republikanin.
} 
To, jak „moskalofobię” Piłsudskiego przedstawił p. Wasilewski, świadczy dobitnie o zawężeniu, uproszczeniu, a więc także zniekształceniu, zarówno postaci zmarłego Marszałka, jak i samego problemu, mającego tak wielkie znaczenie dla losów obydwu narodów.

Interesującym byłoby, a zarazem pożytecznym napisanie historii, nie tyle polsko-rosyjskiej walki, wielowiekowej i jeszcze nie zakończonej, co historii polsko-rosyjskiego odpychania i przyciągania.

Zdumiewające, że w literaturze rosyjskiej Polacy zawsze byli przedstawiani w niekorzystnym świetle, a Rosjanie w literaturze polskiej posiadali najbardziej nikczemne cechy charakteru.

Po wszechświatowej katastrofie i odrodzeniu Polski kwestią tą zainteresowali się Polacy. Cztery lata temu, w pięćdziesiątą rocznicę śmierci Dostojewskiego, Jerzy Stempowski ${ }^{17}$ zamieścił w krakowskim czasopiśmie „Przegląd Współczesny” bardzo interesującą analizę niechęci Dostojewskiego do Polaków (przypomnę tylko, że Dostojewski miał polskie pochodzenie). Stempowski widzi tu całkowicie odmienne podejście do kwestii honoru ze strony samego Dostojewskiego i tych Polaków, których spotkał na katordze. Niedawno prof. Wacław Lednicki ${ }^{18}$ w swojej francuskiej książ$\mathrm{ce}^{19}$ o nacjonalizmie i chrześcijaństwie Lwa Tołstoja (Kraków 1935) pisze, jak wolno ewoluował stosunek Lwa Tołstoja do Polaków. Dopiero gdy został „tołstojowcem”, pozbył się, ogólnie przyjętego wtedy w Rosji, wrogiego albo nawet pogardliwego stosunku do Polaków. Opowiadanie Za co? napisał już w podeszłym wieku, to znaczy w 1905 roku.

Ale teraz interesuje mnie nie tyle stosunek Rosjan do Polaków, tym bardziej że Rosjanie właściwie Polaków nie znali, co stosunek Polaków do Rosjan. Wydaje się, że w tym miejscu powstaje konieczność przewartościowania, i moment jest ku temu jak najbardziej odpowiedni. Polska bowiem wyzwoliła się spod koszmaru zniewolenia, a więc jej „trauma duchowa” nagromadzona przez 150 lat uciemiężenia wreszcie może się zagoić. Rosja natomiast odwrotnie, wpadła $z$ deszczu pod rynnę i znajduje się teraz w najbardziej przerażającej niewoli.

Z punktu widzenia zdrowego rozsądku nienawiść Polaków do Rosjan jest zupełnie zrozumiała. Za co, można zapytać, Polacy mieliby kochać Rosjan? Gdybym był Polakiem, na pewno nienawidziłbym Rosjan głęboką nienawiścią jako gnębicieli i ciemiężycieli mojego narodu, innymi słowy, tak samo, jak teraz nienawidzę bolszewików.

17 Jerzy Stempowski (1893-1969), eseista, krytyk. Wspomniany artykuł to: Polacy w powieściach Dostojewskiego, „Przegląd Współczesny” 1931, z. XXXVII. Przedruk w tomie Eseje dla Kasandry (Paryż 1961).

18 Wacław Lednicki (1891-1967), rusycysta, memuarysta.

19 W. Lednicki, Quelques aspects du nationalisme et du christianisme chez Tolstoi. Kraków 1935. 
Jednak sprawy tej nie wyczerpuje powszechnie znana zasada odpychania.

Zdaje się, że już starożytni Żydzi byli autentycznymi monoteistami i nienawidzili wszystkich możliwych „bałwanów”. Jednak Biblia kanoniczna, która przeszła przez wielokrotną cenzurę żydowskich kapłanów, przynosi wiele dowodów na to, że inni bogowie byli chętnie przyjmowani przez Żydów a także na to, że surowy monoteizm męczył ich i skłaniali się ku „bogom innym”. Dekalog i Pięcioksiąg Mojżesza, a także księgi prorockie pełne są słów świętego oburzenia przeciw odstępcom. Wynika z tego, że wśród Żydów pokusa wielobóstwa czy innobóstwa istniała zawsze. Prorocy musieli energicznie propagować „nienawiść” do innych narodów, żeby uchronić religijną i narodową twarz swojego ludu.

Polscy bojownicy o wolność mieli w sobie coś z żydowskich proroków.

Musieli nieustannie walczyć z rosyjską pokusą. Bulwersowało ich to, że liczni Polacy „ucztowali z Filistynami”, że wśród ich rodaków było wielu moskalofilów. Zdumiewające, że w dzisiejszych czasach fala moskalofilstwa znowu opanowuje młodą Polskę, chociaż na inny, zupełnie nowy sposób. Jeśli samodzierżawie kusiło przede wszystkim polską arystokrację ziemską albo zwykłych aferzystów, to bolszewizm kusi nieco bardziej zdrowe i rozległe środowisko. Z drugiej strony, nawet w kręgach niebolszewickich w Polsce, zainteresowanie Rosją w ostatnim czasie nieprawdopodobnie wzrosło, zwłaszcza zainteresowanie jej literaturą. Można powiedzieć, że cała współczesna poezja tak lub inaczej znajduje się pod wpływem poezji rosyjskiej. Tłumaczy się, i to nieraz wspaniale: Puszkina, Lermontowa, Tiutczewa, Niekrasowa, Błoka, Jesienina i innych. .

A więc moskalofobi starej daty popełniają wielki błąd, stosując zużyte metody antyrosyjskiej propagandy. Na przykład książka p. Kucharzewskiego $^{20}$ Od białego do czerwonego caratu zdecydowanie nie cieszy się powodzeniem wśród młodzieży. Te stare, utarte schematy mają zapach naftaliny babcinego kufra $\mathrm{z}$ rupieciami. Starsze pokolenie było na tyle zajęte propagandą starego typu, walką $\mathrm{z}$ samodzierżawiem i galwanizowaniem postaci Nowosilcowa z Dziadów Mickiewicza, że jakoś przeoczyło zwycięski pochód rusofilskiej pokusy przebranej w nowe szaty. O ile Róża Żeromskiego już nie robi wrażenia, to jego Przedwiośnie, w którym postawił głęboko tragiczne dla Polski pytanie, pozostało jeszcze nie przezwyciężone. Na pytanie postawione w tej powieści jeszcze nie ma odpowiedzi.

Według mnie p. Wasilewski popełnia poważny błąd, idąc w ślady p. Kucharzewskiego, przypisując „moskalofobię” starego typu także Piłsudskiemu. Zbyt oryginalny był Piłsudski, aby zatrzymać się na tym, wczesnym etapie moskalofobii, który niewątpliwie przeszedł, ale który go nie zadowolił.

20 Jan Kucharzewski (1876-1952), polityk, prawnik, historyk. Dzieło Od białego do czerwonego caratu w 7 tomach, ukazywało się w latach 1923-1935. 
Pan Wasilewski opowiada o przybyciu towarzysza Ziuka do Londynu, jakiś czas po jego ucieczce z petersburskiego szpitala św. Mikołaja Cudotwórcy wiosną 1901 roku.

Według p. Wasilewskiego, Piłsudski przyjechał do Londynu, aby odpocząć po tragicznym i ciężkim epizodzie swojej działalności rewolucyjnej.

Publicznie wystąpił w Londynie tylko dwa razy. Po raz pierwszy w klubie PPS, gdzie przygotował referat o powstaniu 1863 roku, drugi - na zebraniu zorganizowanym przez bundowców ${ }^{21}$.

Na tym ostatnim zebraniu Piłsudski mówił po rosyjsku.

„Nie zapomniałem tego przeklętego języka” - powiedział na początku swojego wystąpienia. P. Wasilewski opatruje to następującą, charakterystyczną uwagą: „Ziuk bardzo lubił przeplatać rozmowę najrozmaitszymi charakterystycznymi powiedzeniami i zwrotami, w które obfituje język rosyjski. Przyzwyczajenie to pozostało mu zapewne z czasów pobytu na zesłaniu syberyjskim" (s. 59).

Dalej (s. 60-65) p. Wasilewski podaje szereg przykładów, dowodzących nienawiści Piłsudskiego do Rosji: „Z jego poszczególnych wypowiedzeń ujawniała się głęboka niechęć do Rosji, będąca jednym z zasadniczych rysów jego, że tak powiem, światopoglądu rewolucyjnego. I nie chodziło tu o Rosję urzędową, carską, której jak i my wszyscy z całej duszy nienawidził. Nie lubił też literatury rosyjskiej, która wśród polskich rewolucjonistów miała entuzjastycznych zwolenników. Poszczególne cechy charakteru rosyjskiego usposabiały go krytycznie. Rosyjska bierność zwłaszcza budziła w nim odrazę" (s. 60-61).

Powtarzam i obstaję przy tym, że p. Wasilewski mówi jak było, czyli bynajmniej nie rozmija się z prawdą. Jednak opowieść jego brzmi zbyt anachronicznie i nie przedstawia postaci Piłsudskiego w pełni, zniekształca jego oblicze, pomniejsza historyczne znaczenie, upraszcza jego stosunek do problematyki polsko-rosyjskiej. P. Wasilewski nie uwzględnił tego, że opowieść, nawet najbardziej dokładna o Piłsudskim jako działaczu rewolucyjnym, założycielu partii PPS, bojowniku o wolność, i to jeszcze przed 1905 rokiem, czyli jeszcze przed pierwszą rewolucją rosyjską, brzmi w roku 1935, po śmierci Marszałka Piłsudskiego, spadkobiercy Jagiełły, Stefana Batorego, Kościuszki, odnowiciela tradycji polskich legionów, zupełnie inaczej niż brzmiała w 1902 roku. Zostawszy Naczelnikiem Państwa, Marszałek nie powiedziałby w taki sposób, chociażby z tego powodu, że nie poszedłby na miting bundowców.

21 Bund - rewolucyjna partia żydowska, powstała w 1897, działała przede wszystkim na terytorium Imperium Rosyjskiego. Po rewolucji październikowej w Rosji do 1922, w Polsce w okresie dwudziestolecia, podczas II wojny światowej, aż do rozwiązania w 1949. 
„Nie zapomniałem jeszcze tego przeklętego języka...”

W jakiej sytuacji zostało to powiedziane?

Piłsudski w 1902 roku miał osobiste powody, aby wypowiadać się w ten właśnie sposób. Można powiedzieć, że dopiero co wyrwał się z piekła. Gdyby nie udało mu się uciec, to być może jego praca polityczna mogłaby się skończyć na zawsze. Ale był głęboko przekonany o swoim powołaniu. Ani na chwilę nie można zapominać, że był to człowiek nietuzinkowy, inny niż my.

Obiektywnie miał swoje „taktyczne” powody, aby wypowiedzieć te słowa.

Przecież występował też na zebraniu bundowców, których chciał przeciągnąć na swoją stronę. Zadanie to nie należało do łatwych, ponieważ bundowcy w swej istocie byli zwolennikami Międzynarodówki. Natomiast Żydzi-nacjonaliści nie byli bundowcami. Byli albo ortodoksami, t.j. realizowali swój nacjonalizm w tradycjach religijnych, albo byli syjonistami. Z tych przyczyn bundowcom w 1902 roku (a właściwie do dziś!) duchowo bliższe są ideały rosyjskiej inteligencji rewolucyjnej niż ideały polskich „niepodległościowców”.

Oto kolejna interesująca kwestia z zakresu polsko-rosyjskiego odpychania i przyciągania.

P. Wasilewski podkreśla, że literatura rosyjska miała wśród polskich rewolucjonistów entuzjastycznych zwolenników.

I to nie przypadkowo.

Piłsudski musiał walczyć w Polsce nie tylko z burżuazyjnymi „ugodowcami”. Jeszcze bardziej niebezpieczny punkt stanowiła pokusa rosyjska wśród polskiej inteligencji rewolucyjnej. Gdy Piłsudski i jego zwolennicy wysuwali ideał niezależności narodowej, cała inteligencja rosyjska włącznie $\mathrm{z}$ inteligencją rewolucyjną do tego stopnia była zmęczona rosyjskim nacjonalizmem, że polski nacjonalizm wydawał się jej niebezpieczny oraz reakcyjny. Inteligencja bowiem dusiła się patriotyzmem urzędowym, a słynna triada Uwarowa ${ }^{22}$ : „prawosławie, samodzierżawie i narodowość” wywoływała w niej obrzydzenie w takim samym stopniu, co i epigoni słowianofilstwa. Przecież Pobiedonoscew ${ }^{23}$ także uważał siebie za słowianofila, za spadkobiercę myśli Dostojewskiego! Właśnie stąd bierze się jej ciążenie ku internacjonalizmowi, socjalizmowi, socjaldemokracji. Dążenia te znalazły wówczas zrozumienie wśród inteligencji polskiej. Postępowa inteligencja rosyjska postrzegała socjalizm pepesowców jako system podejrzany i nieortodoksyjny. Stąd cały szereg sprzeczności oraz nieporozumień pomiędzy Piłsudskim a rewolucjonistami rosyjskimi.

Dlatego wspomniane wystąpienie Piłsudskiego w Londynie, w 1902 od

\footnotetext{
22 Sergiej Uwarow (1786-1855), filolog klasyczny, archeolog, 1833-1849 minister oświecenia publicznego.

23 Konstantin Pobiedonoscew (1827-1907), prawnik, publicysta o poglądach konserwatywnych.
} 
strony taktycznej wcale nie było łatwe, więc odbieranie jego wypowiedzi o języku przeklętym w sposób dosłowny jest błędem.

Ale przejdźmy dalej.

Wiadomo powszechnie, że Piłsudski lubił wtrącać rosyjskie słówka do swoich wypowiedzi. Wasilewski uważa, że był to stary nawyk Piłsudskiego, nabyty podczas zesłania na Syberii.

Z jednej strony jest to prawda, $z$ drugiej - nie.

Wszyscy wiedzą, że Piłsudski miał osobowość tak silną oraz niezwykłą, że umiał trzymać na wodzy swoje nawyki. Można powiedzieć, że przez całe swoje długie i niezwykłe życie albo przezwyciężał je, albo po prostu odrzucał. Co więcej, stwarzał nowe nawyki i robił to w sposób genialny. Posiadał bardzo rzadki talent: magię władzy. W tym przejawiała się jedna z jego tajemnic. Magii tej natomiast zupełnie nie było w Kiereńskim ${ }^{24}$. Jako Wódz Naczelny był postacią zaiste tragikomiczną. Natomiast Piłsudski jako były pepesowiec, gdy został głównodowodzącym, marszałkiem, a później dyktatorem, potrafił wypracować nowe nawyki, które imponowały nawet jego przeciwnikom. Działał, jak działa ten, który „posiadł władzę”.

Gdyby uważał, że język rosyjski jest przeklęty, wówczas z łatwością mógłby zrezygnować z nawyku nabytego podczas zsyłki. Ale to przecież nie dotyczyło Piłsudskiego, który z lubością używał rosyjskich powiedzonek, ponieważ był wielkim artystą. Przyjdą czasy, kiedy Polacy będą oceniali jego „utwory” nie tylko od strony politycznej, ale również artystycznej. Jego „utworach” są autentyczne językowe perły, a i w czasie zwykłych rozmów niejednokrotnie zwykł dysputę prowadzić przepięknie, ocierając się o artyzm. Bardzo to dziwne, że polskie czasopisma, poświęcając tyle artykułów temu znakomitemu człowiekowi, w ogóle nie dostrzegły w nim owego talentu. Było w nim coś z Reja, Kochanowskiego, albo Skargi.

Ciekawe, że Piłsudski, już jako Naczelnik Państwa, rozmawiał z Antonim Słonimskim, znanym polskim pisarzem, w „przeklętym” języku. Opowiedział o tym sam Słonimski („Wiadomości Literackie”, nr 23).

$\mathrm{Z}$ inicjatywy pułkownika, obecnie generała Wieniawy-Długoszowskiego, w Belwederze odbyło się przedstawienie szopki do tekstów Słonimskiego, Lechonia i Tuwima.

„Rozmawiałem - wspomina p. Słonimski - kilka minut z Marszałkiem, ale po rosyjsku. Wieniawa, przedstawiając mnie, powiedział żartobliwie: $<$ a oto nasz komunista $>$. Istotnie, miałem wtedy sprawę o podburzanie do obalenia istniejącego ładu w poemacie Czarna wiosna. Piłsudski powiedział: Да, он даже подмахивает на такого русского интеллигента ${ }^{25}$. Odpowie-

24 Aleksandr Kierenski (1881-1970), prawnik, działacz partii eserów, 1917 - premier Rządu Tymczasowego.

25 „Tak, on nawet pozuje na takiego rosyjskiego inteligenta”. 
działem: Да, я интеллигент, это верно ${ }^{26}$ i rozmowa potoczyła się w języku ościennego mocarstwa. Muszę przyznać, że Marszałek znacznie lepiej niż ja władał tym językiem”.

Nie będę zajmował się kwestią, dlaczego Marszałek tak złośliwie zażartował z p. Słonimskiego. Jasne jest, że Marszałek zdjął swoją klątwę z języka rosyjskiego.

Jeszcze większym anachronizmem wieje od opowiadania p. Wasilewskiego o spotkaniu Piłsudskiego z Azefem ${ }^{27}$.

Było to w kwietniu 1905 roku, w Genewie... Właśnie tam odbyło się zebranie przedstawicieli siedmiu partii socjalistycznych, pracujących ówcześnie w Rosji.

Nie prowadzę bynajmniej „badań historycznych”. Piszę po prostu o książce p. Wasilewskiego. Co więcej, książka p. Wasilewskiego nie interesuje mnie sama w sobie, a tylko jako jedna z egzemplifikacji problemów, z którymi stykają się współcześni wielkich ludzi, próbując opowiadać o nich na podstawie własnych wspomnień.

W tej sytuacji nie angażuję się w żadne „badania historyczne” niezbyt odległej przeszłości. Jedynym moim materiałem pozostaje książka p. Wasilewskiego.

Wynika z niej (s. 92-97), że przed zebraniem genewskim w partii PPS omal nie doszło do rozłamu. Mało brakowało, a w partii zatriumfowałaby „pokusa rosyjska”, z tej przyczyny, iż znacznie wzrósł i umocnił się ruch socjaldemokratyczny. Zwolenników owego ruchu określano jako „lewicę”, co zresztą było niezwykle charakterystyczne.

„Lewica” popierała rewolucję rosyjską, wierzyła w triumf socjaldemokracji i była zdania, że „potoki” socjalistyczne należy skierować do „morza” socjalistycznego wszechrosyjskiej rewolucji imperialnej. W takich warunkach niepodległość państwowa Polski stała na drugim miejscu. W ustroju socjalistycznym ta czy inna forma „autonomii” ma nieco większe znaczenie aniżeli w ustroju burżuazyjnym niepodległość.

Rozbieżności te ujawniły się z osobliwą ostrością na siódmym zjeździe PPS, w marcu 1905 roku. Starzy partyjni „niepodległościowcy” (p. Wasilewski wymienia Jodkę ${ }^{28}$, Jędrzejowskiego ${ }^{29}$, Sulkiewicza ${ }^{30}$ i siebie) zostali odsunięci przez „lewicę”.

Piłsudski nie chciał rozłamu i dlatego, by nie pogłębiać konfliktu, nawet nie był obecny na zjeździe marcowym. Po owym zjeździe liczna grupa „sta-

\footnotetext{
26 „Tak, z pewnością jestem inteligentem”.

27 Jewno Azef (1869-1918), przywódca organizacji bojowej eserów, w 1908 zdemaskowany jako agent ochrany.

28 Witold Jodko Narkiewicz (1864-1924), lekarz, publicysta, działacz PPS, dyplomata.

29 Bolesław Jędrzejowski (1867-1914), działacz PPS, wydawca.

30 Aleksander Sulkiewicz (1867-1916), działacz PPS, żołnierz Legionów.
}

304 colloquia Humanistica 
rych” pepesowców przeszła do pracy technicznej czy bojowej. Rozpadowi udało się zapobiec, a Piłsudski został wybrany na delegata partii na zjazd genewski (s. 93-95).

„Po powrocie z konferencji Ziuk dzielił się z nami swoimi wrażeniami. Wypadek chciał, że jako reprezentant rosyjskiej partii S.R.(socjalistów rewolucjonistów) na konferencji genewskiej występował Jewno Azef, głośny niebawem, jako zdemaskowany przez Burcewa agent-prowokator.

Mówiąc o nim, Ziuk wyraził się: Dosyć mi się podobał ten Żydowin...

Takie wrażenie wywarł na Ziuku Azef, zdaje się, głównie tym, że w dłuższej rozmowie z nim dość lekceważąco odzywał się о револющионных качествах русского человека ${ }^{31}$.

Cytat ten wyraźnie pokazuje, jak bardzo metoda p. Wasilewskiego jest niewłaściwa, a także jakim zniekształceniom perspektywy historycznej grzeszą jego wspomnienia.

Wszystko, co komunikuje p. Wasilewski, jest zupełne prawdziwe a zarazem głęboko mylne.

Rzecz jasna, w kwietniu 1905 roku nikt nie dopuszczał takich myśli, że Azef jest prowokatorem, a tym bardziej, że Gapon ${ }^{32}$ w najbliższej przyszłości może zostać „konfidentem” albo „współpracownikiem” Departamentu Policji.

Piłsudski także nie dopuszczał takiej możliwości, dlatego zupełnie oczywiste jest, że ze wszystkich delegatów najbardziej musiał zainteresować go Azef. Partia rosyjskich socjalistów-rewolucjonistów była $z$ natury swojej najbliższa pepesowcom odłamu piłsudczykowskiego. Eserzy ${ }^{33}$ byli mniej „internacjonalistyczni” niż socjaldemokraci, oprócz tego „marksizm” klasyczny niezbyt im odpowiadał. Partia ich była duchowo związana z Hercenem, Michajłowskim, z narodnikami ${ }^{34}$, „narodowolcami”. Każdy z nich, przynajmniej w latach młodości, czytał artykuły Michajłowskiego Bohate-

\footnotetext{
31 Rewolucyjnych właściwościach rosyjskiego człowieka.

32 Georgij Gapon (1870-1906), duchowny prawosławny, organizator lojalistycznej organizacji robotniczej, inspirowanej przez policję. W 1905, po aresztowaniu kilku działaczy tego ruchu, Gapon zainicjował marsz na Pałac Zimowy w celu złożenia petycji na ręce cara. Manifestacja (9 stycznia) została zmasakrowana. Na emigracji Gapon związał się z partią eserów, próbował zdemaskować Azefa, za co po powrocie do Rosji został zabity przez eserowską bojówkę.

33 Eserzy - Partia Socjalistów-Rewolucjonistów, powstała w 1901, posługująca się terrorem indywidualnym, po rewolucji październikowej jej działacze i członkowie podlegali prześladowaniom w Rosji sowieckiej.

34 Narodniczestwo - ideologia inteligencji rosyjskiej rozwinięta od lat 60. XIX w., oparta na poszukiwaniu mądrości w ludzie, rysująca perspektywę zmiany ustrojowej poprzez powrót do tradycyjnej wspólnoty. Z ideologii tej czerpała tajna organizacja Ziemla i Wola, a następnie terrorystyczna Narodna Wola (powstała w 1879). Za ideowych twórców narodniczestwa uważa się między innymi Aleksandra Hercena i Nikołaja Michajłowskiego.
} 
rowie i tłum (powstały z inspiracji Carlylem ${ }^{35}$ ). Czernyszewski był dla nich postacią szanowaną, ale obcą, natomiast Gleba Uspienskiego ${ }^{36}$ i Władimira Korolenkę ${ }^{37}$ darzyli nie tylko uznaniem, ale i miłością. Nawiasem mówiąc, pierwsza żona Sawinkowa była córką Gleba Uspienskiego.

Wreszcie, partia miała O.B. [Organizację Bojową - tłum], która przed konferencją genewską w kwietniu 1905 roku dała o sobie znać, dokonując szeregu aktów terrorystycznych. Piłsudski doskonale rozeznawał się w rosyjskich partiach rewolucyjnych, i to oczywiste, iż delegat partii socjal-rewolucyjnej zainteresował go bardziej niż inni.

Z Gaponem nie miał o czym i po co rozmawiać. Po 9 stycznia 1905 roku Gapon jako osobowość, jako ktoś mający realną siłę, przestał istnieć. Jeśli ktokolwiek wykorzystał jego czasową popularność w celu zwołania konferencji genewskiej „Z jego inicjatywy”, to wątpię, czy inicjatywa ta była realna.

Gapon jest jednym z najbardziej interesujących i oryginalnych epizodów w historii rosyjskiego ruchu rewolucyjnego. Gdyby zginął 9 stycznia razem $z$ setkami rozstrzelanych robotników, zostałby legendą. Zająłby wtedy miejsce gdzieś w kręgu Lamennaisa ${ }^{38}$. Nawet przeciwnicy rewolucji zamyślaliby się nad jego śmiercią. Prawosławny pop w sutannie, z krzyżem w rękach prowadzi nieuzbrojony tłum robotników na Pałac Zimowy, żeby powiedzieć carowi o potrzebach „maluczkich” oraz prosić wszechmocnego o pomoc w imię prawdy chrześcijańskiej.

Przygotowania 9 stycznia zaniepokoiły postępową inteligencję i wprowadziły w pewne zakłopotanie. Świadczy o tym zebranie przedstawicieli rozmaitych grup inteligenckich w wydawnictwie „Сын отечества” w nocy z 8 na 9 stycznia. O tym zebraniu nie raz pisano w prasie. Wszyscy przeczuwali, że inicjatywa Gapona nie skończy się dobrze. Ale w międzyczasie, gdy jedni uważali to za prowokację policyjną, inni brali pod uwagę naiwność polityczną Gapona i jego następców. W każdym razie wybrano delegację, która skierowała się do ówczesnego ministra spraw wewnętrznych księcia Światopełk-Mirskiego ${ }^{39}$. Wiadomo, że wszyscy członkowie delegacji, z wyjątkiem sędziwego K.K. Arseniewa ${ }^{40}$, zostali aresztowani, a pochód robotników przywitano strzałami karabinów wojska, strzegącego Pałacu Zimowego.

\footnotetext{
35 Thomas Carlyle (1795-1881), szkocki pisarz i myśliciel, ideolog imperializmu brytyjskiego. Wyrazem jego poglądów na szczególną rolę jednostki w historii jest książka Bohaterowie.

36 Gleb Uspienski (1843-1902), prozaik.

37 Władimir Korolenko (1853-1921), pisarz, dziennikarz, działacz społeczny.

38 Hugues-Félicité-Robert de Lamennais (1782-1854), ksiądz katolicki, później polityk, postulował odnowę Kościoła, podnosił kwestie nierówności społecznych.

39 Piotr Światopełk-Mirski (1857-1914), generał-gubernator wileński, 1904-1905 minister spraw wewnętrznych.

40 Konstantin Konstantinowicz Arseniew (1837-1919), publicysta, pisarz, działacz ziemski.
} 
Gapon niestety się uratował.

Tego samego dnia w sali Niezależnego Stowarzyszenia Gospodarczego odbyło się tłumne zebranie, na którym perorował, niby „incognito”, ostrzyżony i ogolony Gapon w „marynarce”.

Niewielki pałacyk z czasów Katarzyny gdzieś przy prospekcie Zabałkańskim, zagubiony wśród pokracznych i ogromnych, późniejszej daty, budynków. Typowa sala z kolumnami. Niewielkie loże „dla muzyków”. Jakby dekoracja do opery Czajkowskiego Eugeniusz Oniegin. W pewnym momencie „w loży” ukazał się Maksym Gorki w czarnej koszuli.

$\mathrm{Na}$ sali panowało ogromne napięcie. Maksym Gorki wyolbrzymiał je jeszcze bardziej swoim histerycznym zachowaniem. Pod koniec swojego porywającego przemówienia powiedział, że teraz wystąpi pewna, znana mu dobrze „osoba”, aktywnie uczestnicząca w tragicznym „pochodzie”. Ta nieco naiwna konspiracja wywołała pożądany efekt, a spojrzenia całej sali zatrzymały się na nowym mówcy. W loży, obok Gorkiego ukazał się Gapon i natychmiast wpadł w jeszcze bardziej zaawansowaną histerię niż Gorki. Rzecz jasna, to fryzjer, który go obciął, spełnił rolę Dalili, która przyczyniła się do tego, że ostrzyżony Samson stracił swoją moc. Została po nim wyłącznie „firma”, którą można było wykorzystywać w przypadku posiadania odpowiednich umiejętności.

Nie wiem, jaką rolę pełnił Gapon na zebraniu w Genewie, ale przypuszczam, że nie miał wielkiego znaczenia. P. Wasilewski nic o nim nie mówi w swoich wspomnieniach. Zdaje się, że Piłsudski potraktował go z całkowitą obojętnością, co zrozumiałe i skupił się przede wszystkim na Azefie.

Łamiąc zasadę obiektywności epickiej, p. Wasilewski proponuje swoją interpretację wypowiedzi Piłsudskiego o Azefie. „Takie wrażenie wywarł na Ziuku Azef, zdaje się, głównie tym, że w dłuższej rozmowie z nim dość lekceważąco odzywał się о революционных качествах русского человека”(s. 97).

Interpretacja ta, przedstawiona w maju 1935 roku brzmi zbyt naiwnie.

P. Wasilewski nie uwzględnił tej okoliczności, że Azef sam z siebie był kimś godnym uwagi, a co najważniejsze, był szalenie zainteresowany Piłsudskim.

Literatura o Azefie jest ogromna. Nie rozstrzyga ona jednak jednej, głównej kwestii. Do tej pory nie jest jasne, komu Azef wyrządził największą szkodę: czy swoim towarzyszom i ruchowi rewolucyjnemu w ogóle, czy rosyjskiemu rządowi i bezpośrednio własnym zwierzchnikom. W każdym razie, w porównaniu z tym diabelskim człowiekiem, dyrektor Departamentu Policji Łopuchin ${ }^{41}$, „krewny” rosyjskiej carycy z końca XVII wieku ${ }^{42}$, wydaje

${ }^{41}$ Aleksiej Łopuchin (1864-1928), prawnik, prokurator, 1902-1905 dyrektor Departamentu Policji, zwolniony za liberalne i „populistyczne” stanowisko w walce z ruchem rewolucyjnym, brał udział w zdemaskowaniu Azefa jako agenta policji.

42 Mowa o Jewdokii (właśc. Praskowii Łopuchinej), pierwszej żonie cara Piotra I. 
się żółtodziobem. Nie chce się wierzyć, że to nasi rosyjscy „Fouché” tak beztrosko igrali z ogniem. Prawdziwy Fouché nie popełniłby takiego głupstwa. Piłsudski nie wątpił w uczciwość rewolucyjną Azefa. Ale, oczywiście wiedział o nim zbyt mało, ponieważ O.B. socjalistów-rewolucjonistów zachowywała konspirację, a dla Azefa owa konspiracja była bardzo ważna. Z drugiej strony, Azef bardzo dobrze znał Piłsudskiego (może z dokumentów tego samego Departamentu Policji?).W każdym razie zależało mu bardzo, aby zbudować przyjazne stosunki z Piłsudskim. W tym celu zrobił wszystko, żeby wywrzeć dobre wrażenie na swoim rozmówcy, co po części mu się udało. Azef grał rolę „szczerego” człowieka, a uwzględniając pozycję Piłsudskiego, który nie chciał wiązać się z rosyjskimi rewolucjonistami, przytakiwał mu we wszystkim oraz dowodził, że nie wierzy we właściwości rewolucyjne Rosjan. Zbyt jednak ostrożnym człowiekiem był Piłsudski i zbyt doświadczonym konspiratorem, żeby być całkowicie szczerym wobec „sympatycznego Żydowina”, ale też szalenie inteligentny i podstępny Azef zaufania od Piłsudskiego nie oczekiwał. Sam fakt „długiej rozmowy” był dla niego zupełnie wystarczającym, i podnosił jego akcje tak w oczach naszych rosyjskich „Fouché”, jak i w oczach partyjnych towarzyszy.

W takich okolicznościach „interpretacja” p. Wasilewskiego wydaje się zbyt prosta.

Jeszcze bardziej dziwi mnie znaczenie, jakie Wasilewski przypisuje pogardliwym słowom Azefa o „właściwościach rewolucyjnych Rosjanina”.

W kwietniu 1905 roku słowa te miałyby sens. Ale w maju 1935 roku brzmią nieco anachronicznie. Wypowiedziane były na kilka miesięcy przed październikiem 1905 roku, to jest przed rewolucją. Długotrwały strajk powszechny podważył w dużym stopniu słowa Azefa. W strajku uczestniczyły różne warstwy społeczne. Jeśli rewolucja 1905 roku nie uwolniła żywych i twórczych sił narodu rosyjskiego, nie odświeżyła państwowości rosyjskiej w wystarczającym stopniu, to nie dlatego, że naród rosyjski nie posiada cech rewolucyjnych, ale dlatego, że brakowało zmysłu państwowego rosyjskim partiom rewolucyjnym, a zwłaszcza kręgom rządzącym. Jednak nie jest to odpowiednie miejsce, aby wdawać się w wyjaśnienia historyczne. Podam tylko dwa jaskrawe przykłady: bojkot przez eserów wyborów do Dumy Państwowej, a także słynny „apel wyborgski” ${ }^{43}$, przeniknięty jakimś politycznym „tołstojostwem”.

Jeszcze bardziej przeczy „interpretacji” p. Wasilewskiego rewolucja bolszewicka. Niezależnie od tego, jaki mamy do niej stosunek, niewątpliwie wej-

\footnotetext{
43 Po rozpuszczeniu I Dumy deputowani (ok.200) na znak protestu zebrali się w Wyborgu i przygotowali „apel do narodu ”. Wzywał on ludność do częściowego nieprzestrzegania prawa cywilnego (m.in. niepłacenia podatków) ponieważ bez udziału przedstawicieli narodu rząd nie ma prawa do wydawania niektórych decyzji. Naród jednak nie zareagował.
} 
dzie do podręczników wszystkich narodów jako rewolucja o światowym znaczeniu, o rozmachu dużo większym niż rewolucja francuska 1789 roku.

Właśnie w tym miejscu być może mamy do czynienia z genialnym przeczuciem Piłsudskiego. W roku 1905 może działał on podświadomie, kierując się intuicją. Wszystko jedno, nie zmienia to istoty rzeczy. Od początku zdecydowanie był za „niepodległością” Polski, walczył z „lewicą” swojej własnej partii, bał się współpracy z rewolucją rosyjską, ponieważ z jednej strony dążył do samodzielności Polski jako państwa, zaś z drugiej nie ufał zmysłowi państwowemu rewolucjonistów rosyjskich.

Co więcej, dalsza jego działalność, już w niepodległej Polsce, świadczy o tym, że w tej kwestii odczuwał wielką trwogę o swój własny naród. Historia Polski, prace historyczne szkoły krakowskiej na czele $\mathrm{z}$ dopiero co zmarłym Bobrzyńskim ${ }^{44}$, dawały mu wiele powodów do takiej trwogi. Mówiąc skrótowo, na pierwszym miejscu stawiał utworzenie państwowości w niepodległej Polsce. Najpierw być, później filozofować. Na początku państwowość, a później kwestie socjalne. Nie przypadkiem tylu wybitnych przedstawicieli lewicy, z którą Piłsudski walczył jeszcze w 1905 roku, przeszło na stronę bolszewików. Kto wie, czy zbyt szerokie przywileje socjalne nie przekształciłyby Polski w „Republikę Tatarską” ZSSR? Dla zachowania państwowości polskiej, której widomym symbolem jest dobre wojsko, decydował się na wielkie ofiary oraz stawiał współobywatelom wysokie wymagania. To wyjaśnia surowe zarzuty pod adresem Polaków, zarzuty, którymi przeniknięte są jego mowy.

Jeśli więc ja, będąc przedstawicielem tego narodu, którego Piłsudski, według interpretacji p. Wasilewskiego nienawidził do szpiku kości, darzę go wielkim szacunkiem, to właśnie dlatego, że brakowało Rosji takiego Piłsudskiego. Naród rosyjski posiada aż za wiele „cech” rewolucyjnych, a świadomego, twardego podejścia do rozumnej państwowości jak nie było, tak nie ma. Jak wszyscy Słowianie, grzeszy anarchizmem. Rewolucja 1905 roku nie stworzyła Piłsudskiego ani w obozie rewolucjonistów, ani w obozie rządowym. Natomiast przewrót bolszewicki stworzył ignoranckiego, prowincjonalnego pyszałka, Kita Kitycza ${ }^{45}$ rodem z Ostrowskiego. Zdecydowanie nie wiadomo, czego chce jego lewa noga.

$\mathrm{Na}$ tle dalszych wielkich wydarzeń oraz konstruktywnej działalności państwowej Piłsudskiego wspomnienia p. Wasilewskiego, a zwłaszcza jego interpretacje, są nieco jednostronne.

\footnotetext{
44 Michał Bobrzyński (1849-1935), współtwórca krakowskiej szkoły historycznej, polityk konserwatysta, 1908-1913 namiestnik Galicji.

45 Postać z komedii В чужом пиру похмелье Aleksandra Ostowskiego (1856). Jedna z postaci nazywa ironicznie Tita Titycza Bruskowa Kitem Kityczem. Człowiek zarozumiały, ignorant, despotyczny.
} 
Chociaż wielka była rola Piłsudskiego jako rewolucjonisty, konspiratora, bojownika o niepodległość Polski, jednak na pierwszym miejscu powinno się postawić jego działalność w stworzeniu polskiej suwerenności oraz państwowości.

Życie człowieka wielkiego ma swoje prawa. Analizując oddzielne etapy jego twórczej drogi, należy zawsze pamiętać o całej drodze, inaczej można dokonać zniekształceń.

Uwzględniając to, co zostało napisane, można wreszcie podsumować oraz wyprowadzić pewne wnioski...

Pierwsza nauka, płynąca z książki p. Wasilewskiego głosi, że podobnego rodzaju wspomnień nie należy ogłaszać tuż po śmierci człowieka, o którym się pisze. Gdyby zostały one opublikowane nie w 1935 roku, a w 1985, byłyby niezmiernie wartościowym materiałem dla przyszłych historyków, o ile oczywiście potrafiliby materiał taki należycie wykorzystać. Wydane zaś niemalże nazajutrz po śmierci Marszałka (wstęp opatrzony jest datą 19 maja 1935 roku), nie mogą być odebrane właściwie, ponieważ zniekształcają oblicze zmarłego.

Mogą mi zarzucić, że jako rosyjski emigrant, w kwestii tej nie powienienem się wypowiadać oraz, że moja argumentacja jest jednostronna, ponieważ w moim artykule poruszyłem tylko stosunek Marszałka do Rosji, ignorując pozostałe, bardzo cenne wątki wspomnień p. Wasilewskiego.

Takie zarzuty nie są słuszne. Ograniczyłem się do problematyki rosyjskiej nie tylko dlatego, że jest mi bliższa i droższa niż inne. Wydaje mi się, że tak uparte wysuwanie na pierwszy plan „moskalofobii” Marszałka Piłsudskiego prowadzi do zawężenia a nawet zniekształcenia jego oblicza, to tak, jakby wysuwano na plan pierwszy jego germanofilstwo. Dla przyszłych historyków Piłsudski będzie przede wszystkim polskim patriotą, a nie moskalofobem czy germanofilem.

$\mathrm{Z}$ drugiej strony, co w tym przypadku jest znacznie bardziej istotne, ograniczyłem się do „rosyjskich” argumentów właśnie dlatego, że jestem rosyjskim emigrantem, a zatem nikt nie może mi zarzucić „ingerencji” w sprawy polskie. Zbyt dużo poświęciłem czasu i sił na problematykę rosyjsko-polską, zbyt dużo miałem konfliktów z przedstawicielami emigracji rosyjskiej, aby nie mieć prawa do takiej „ingerencji”. Tylko dlatego unikałem argumentów innego charakteru. A przecież mógłbym przytoczyć je w wystarczającej ilości...

Kolejna nauka brzmi następująco.

Jak wszyscy ludzie wielcy, Piłsudski posiadał osobowość tragiczną. Był w ciągłym ruchu, w ciągłym napięciu. Nieustannie wspinał się w górę, na 
szczyt owego Mont Blanc, by spotkać swoją jedyną „Piękną Damę"46.

W takiej świadomości tragizmu, w takim ruchu i napięciu pozostawało wielu ludzi wielkich, na przykład Friedrich Nietzsche, który zresztą z wyglądu bardzo przypomina Piłsudskiego. Nieustannie iść do przodu, nieustannie stawiać na kartę swoje ,istnienie” można nie tylko w walce i działaniach zewnętrznych, ale też siedząc w swoim gabinecie przy biurku jak Nietzsche...

Nie każdy potrafi znieść takie napięcie, takie „ciśnienie” wielu „atmosfer”. Dlatego wielcy ludzie mają tak mało towarzyszy-sprzymierzeńców, z którymi przeszli drogę razem od początku do końca. Droga wielkiego człowieka w sposób nieunikniony wiąże się z oderwaniem się, zerwaniem, w końcu - z samotnością. W tym między innymi przejawia się jego tragizm. Człowiek wielki ma o wiele więcej poputczyków ${ }^{47}$ niż towarzyszy-sprzymierzeńców. Ale poputczycy w swej istocie są świadkami jednostronnymi. Oni są w stanie „wspominać” tylko jeden etap z życia wybitnego człowieka, jedynie odcinek jego drogi, przy tym wcale nie najważniejszy.

Dla przykładu odwołajmy się znowu do Fryderyka Nietzschego.

Jak wiadomo, w pierwszym, romantycznym okresie swojej twórczości był blisko Ryszarda Wagnera. Zaczynając od Narodzin tragedii (1872) i kończąc Ryszardem Wagnerem w Bayreuth (1876), Friedrich Nietzsche trwał w kręgu idei bardzo bliskich Wagnerowi, co sprawiało, iż wielu z ówczesnych przyjaciół i współpracowników Wagnera patrzyło na młodego filologa i myśliciela jako na utalentowanego interpretatora genialnego kompozytora.

Ale Nietzsche nie byłby Fryderykiem Nietzsche, gdyby utkwił na płaskowyżu Bayreuth. Jego droga wiodła dalej i wyżej i dlatego, zarzuciwszy na plecy swój tobołek pielgrzyma, porzucił Bayreuth. W tych dawnych latach zerwanie Nietzschego z Wagnerem wywołało wielki rozgłos, zwłaszcza że Nietzsche publicznie spalił wszystko, co do tej pory czcił. Targnął się na świątynię Wagnera, przeciwstawił Pierścieniowi Nibelunga operę Bizeta Carmen. Świętokradztwo to pogłębiała jeszcze okoliczność, że Bayreuth było wtenczas świątynią tylko dla wybranych i podlegało ostremu ostrzałowi przez wielbicieli... Offenbacha. Ludzie Bayreuth mieli na swój sposób rację. Ich walka o pierwszeństwo jeszcze nie była skończona, uważali bowiem siebie za ostatnie i najwyższe osiągnięcie, a Nietzsche uznał ich za swoich poputczyków na jednym z pierwszych etapów własnej drogi wzwyż.

Nietzsche wszedł w fazę swoistego „wolterianizmu”, fazę żrącego sceptycyzmu, fazę walki ze wszystkimi przejawami romantyzmu i mistycyzmu.

${ }^{46}$ Aluzja do Wierszy o Pięknej Damie Aleksandra Błoka.

47 Słowo nonymчuк, właściwie nieprzetłumaczalne, pozostawiamy $\mathrm{w}$ oryginale, ponieważ bywa ono stosowane w polskim języku literackim. 
Zaczęli mu towarzyszyć nowi poputczycy, którzy także szczerze myśleli, że są jego „sprzymierzeńcami”.

Ale nie spełnił ich oczekiwań. Wkrótce nastąpił trzeci i ostatni etap drogi Friedricha Nietzschego.

Rzecz jasna, w obszernej literaturze o Nietzschem wielkie znaczenie mają wspomnienia poputczykow.

Poputczycy pierwszego okresu przedstawiali go jako neoromantyka w rodzaju Wagnera, zaś poputczycy drugiego okresu - jako bezwzględnego sceptyka i pamflecistę.

Pierwsi - $\mathrm{z}$ ubolewaniem podkreślali jego zdradę wobec Wagnera, drudzy z tym samym uczuciem podkreślali jego zdradę na rzecz „wolterianizmu”, jego fascynację nową formą „bezbożnego mistycyzmu ”.

Dopiero następne pokolenia spojrzały na Fryderyka Nietzschego z perspektywy czasu, jako na kogoś doskonałego, scalonego, zrozumiały jego drogę nieustannie wiodącą wzwyż. Autorzy wspomnień są zawsze poputczykami. Zatrzymują się na znanym im etapie i dalsza droga wydaje im się nie wstępowaniem, a zstępowaniem. $Z$ tego powodu nieświadomie przyjmują pozę sędziów, przy tym sędziów dalece nie obiektywnych.

Wracając do ksiązki p. Wasilewskiego można powiedzieć tak: pierwsza połowa książki [jej rozdziały:] Towarzysz Wiktor i Ziuk - przedstawiają wzlot Piłsudskiego.

W trzeciej części, w Komendancie, pojawia się jakiś problem. Odnosi się wrażenie, że p. Wasilewski nieco się pogubił. Sam do tego przyznaje się otwarcie. W niezwykłe prostolinijny sposób podkreśla, że „wojskowe” zainteresowania Piłsudskiego były mu obce, i że on, Wasilewski, świadomie pozostał w kręgu „cywilów”.

Czwarta część, Naczelnik Państwa, napisana, już nie od wewnątrz, a z zewnątrz. Wieje od niej chłodem obserwatora.

Kończy się zaś książka opisem ostatniego spotkania z Marszałkiem, na początku maja 1926 roku.

W tym najbardziej odpowiedzialnym momencie „wspinaczki” Marszałka p. Wasilewski udał się do Sulejówka, razem z p. Woszczyńską ${ }^{48}$, aby prosić Piłsudskiego o udział w uroczystym zebraniu, poświęconym pamięci p. Paszkowskiej ${ }^{49}$, „wybitnej działaczki z czasów, kiedy Piłsudski był przywódcą PPS”.

\footnotetext{
48 Stanisława Woszczyńska (1879-1967), działaczka PPS od 1904, dziennikarka, członkini Rady Naczelnej PPS (1910-1921 i 1928-1939), w 1945 współinicjatorka założenia Polskiej Partii Socjalno-Demokratycznej.

49 Maria Paszkowska (1859-1925), działaczka II Proletariatu, w PPS od 1893, działaczka Organizacji Bojowej PPS i PPS - Frakcji Rewolucyjnej. Po 1914 poświęciła się pracy społecznej na rzecz dzieci. W 1901 organizatorka ucieczki Józefa Piłsudskiego ze szpitala św. Mikołaja Cudotwórcy.
} 
„Piłsudski wyszedł do nas - opowiada Wasilewski - w nastroju dość ponurym, ale obiecał, że przybędzie na akademię. Widać było, że jakieś poważne troski zaprzątają go w tej chwili i że naszą prośbę traktuje zupełnie formalnie... Było to moje ostatnie spotkanie osobiste z Marszałkiem Piłsudskim" (s. 232-233).

Czytelnikowi postronnemu, w żaden sposób nie mającemu do czynienia z historią Polski dwudziestego wieku, we wspomnieniach p. Wasilewskiego opowiada się o tym, jak wspinał się Piłsudski w okresie swojej działalności rewolucyjnej, a także jak powoli zwalniał tempo wspinaczki, poczynając od bohaterskiej epopei Legionów, aż ostatecznie zatrzymał się po przewrocie majowym.

Oto trzecia i ostatnia nauka. Każdy autor wspomnień o wielkim człowieku powinien nieustannie uświadamiać sobie, że jest tylko poputczykiem wielkiego człowieka na jednym z etapów jego wielkiej drogi. Ponadto powinien dobitnie wyjaśnić to swoim czytelnikom; nie czyniąc tego, może wprowadzić ich w błąd.

„Меч” 1935, nr 26 (7.07), 27 (14.07), 28 (21.07), 30 (4. 08)

Przekład z języka rosyjskiego:

Swiatłana Kuziur-Chrostowska

i Piotr Mitzner

\section{Zachowany fragment wersji rękopiśmiennej}

W archiwum Bożeny Mikułowskiej w Warszawie znajdują się okruchy prywatnego archiwum Dymitra Fiłosofowa. Wśród jego rękopisów jest też początek odrzuconej później przez autora wersji artykułu o Piłsudskim.

Dla mnie, rosyjskiego emigranta ogromnie trudnym zadaniem jest pisanie o Marszałku, zwłaszcza tuż po jego śmierci.

Dlatego, nim przystąpię do realizacji tego zamiaru, muszę wyjaśnić, choćby pokrótce, co skłoniło mnie, bym chwycił za pióro, nie bacząc na tak liczne przeszkody.

Pierwsze pytanie, jakie zadaje sobie każdy, kto pisze, a tym bardziej publikuje wspomnienia o swoim wielkim współczesnym, brzmi: czy mam do tego prawo?

Powiem od razu, że nie wydaje mi się, iżbym miał takie prawo.

Rzecz jasna ten krótki czas, gdy znalazłem się w orbicie tak różnorodnej działalności tego niezwykłego człowieka, godny jest uwagi. Można powiedzieć, że w tych latach ważyły się losy, dopiero co odrodzonej, jeszcze nieokrzepłej Polski, w tych latach krystalizowała się nieunikniona tragedia mojej Ojczyzny. 
Z tego bynajmniej jeszcze nie wynika, że mam prawo dorzucać swoje trzy grosze (jak mówią Polacy) do biografii Józefa Piłsudskiego, opowiadać, jak nieoczekiwanie i osobliwie spotkały się nasze drogi, jak dziwne i wyjątkowe były nasze rozmowy. Celowo podkreśliłem słowo nasze, by pokazać w jak trudnym i niezręcznym położeniu może się znaleźć ktoś, kto zdecyduje się na takie wspomnienia. W pewnej starej francuskiej komedii ${ }^{50}$ pan Perrichon, typowy francuski mieszczuch, zachwyca się szczytem Mont Blanc i rozważa kwestię: ja i Mont Blanc. Efekt jest wyjątkowo komiczny. Okazuje się jednak, że jakiekolwiek wspomnienia bez Ja (le Moi méprisable $e^{51}$ Pascala), a czasem nawet bez My - technicznie są po prostu niemożliwe.

\section{Przekład z języka rosyjskiego Piotr Mitzner, przypisy historyczne Swiatłana Kuziur-Chrostowska}

50 Eugen Labiche i Edouard Martin, Podróż pana Perrichon.

51 Pomyłka autora, stosowny cytat z Myśli Pascala brzmi: Le moi est haïssable, sens jest jednak niemal ten sam: „Ja jest wstrętne” (B. Pascal, Myśli. Przekład T. Żeleńskiego (Boya). Warszawa 1977, s. 75. Fragment 136 [75].

314 COLloquia HUMANISTICA 